\title{
PENGARUH MODEL PEMBELAJARAN BERBASIS PROYEK TERHADAP KREATIVITAS SISWA SMP PADA PEMBELAJARAN IPA
}

\author{
Ade Sintia Wulandari, I Nyoman Suardana, N. L. Pande Latria Devi \\ Program Studi S1 Pendidikan IPA \\ Universitas Pendidikan Ganesha \\ Singaraja, Indonesia
}

e-mail: \{sintia.wulandari, nyoman.suardana, latria.devi\} @undiksha.ac.id

\begin{abstract}
Abstrak
Penelitian ini bertujuan mendeskripsikan pengaruh model pembelajaran berbasis proyek terhadap kreativitas siswa SMP pada pembelajaran IPA. Penelitian ini merupakan penelitian eksperimen semu dengan rancangan non-equivalent pretestposttest control group design. Populasi dalam penelitian ini adalah seluruh siswa kelas VII SMP Negeri 3 Sukasada tahun ajaran 2017/2018 yang terdiri atas 150 orang yang tersebar ke dalam 5 kelas. Sampel dipilih menggunakan teknik cluster random sampling sebanyak dua kelas yaitu siswa kelas VIID sebagai kelas eksperimen diterapkan model pembelajaran berbasis proyek (PjBL) dan siswa kelas VIIE sebagai kelas kontrol diterapkan model kooperatif tipe Student Teams Achievement Division (STAD). Objek penelitian ini adalah kreativitas siswa yang dikumpulkan menggunakan metode tes. Data kreativitas dianalisis menggunakan teknik analisis statistik deskriptif dan statistik inferensial. Statistik deskriptif digunakan untuk mendeskripsikan hasil rata-rata kreativitas siswa sedangkan statistik inferensial digunakan untuk menguji hipotesis penelitian menggunakan uji ANCOVA satu jalur dengan taraf signifikansi 0,05 . Hasil penelitian menunjukkan bahwa siswa yang dibelajarkan menggunakan model PjBL lebih baik dari siswa yang dibelajarkan menggunakan model pembelajaran kooperatif tipe STAD. Hal tersebut ditunjukkan oleh skor rata-rata posttest pada kelompok model PjBL dan kelompok model kooperatif tipe STAD berturut-turut sebesar 88,67 dan 33,86 .
\end{abstract}

Kata kunci: Model pembelajaran berbasis proyek, model kooperatif tipe Student Teams Achievement Division, kreativitas

\begin{abstract}
This study aim to describe the effect of project-based learning models on the creativity of junior high school students in science learning. This research is a quasiexperimental study with non-equivalent pretest-posttest control group design. The population in this study were all seventh grade students of SMP Negeri 3 Sukasada in the 2017/2018 school year consisting of 150 people who were spread into 5 classes. The sample was selected using two classes of cluster random sampling technique, namely the VIID class as the experimental class applied to the projectbased learning model (PjBL) and class VIIE students as the control class applied the cooperative model type Student Teams Achievement Division (STAD). The object of this research is the creativity of students collected using the test method. Creativity data were analyzed using descriptive statistical analysis techniques and inferential statistics. Descriptive statistics are used to describe the results of the average student creativity while inferential statistics are used to test the research hypothesis using a one-way ANCOVA test with a significance level of 0.05 . The results showed that students who were taught using the PjBL model were better than students who were taught using the STAD type cooperative learning model. This is shown by the posttest mean score in the PjBL model group and the STAD type cooperative model group respectively 88,67 and 33,86 .
\end{abstract}

Keywords: Project-based learning model, cooperative model of Student Teams Achievement Division type, creativity 


\section{PENDAHULUAN}

Pendidikan di abad 21 bertujuan untuk membangun kemampuan intelegensi siswa dalam pembelajaran agar mampu menyelesaikan permasalahan yang ada di sekitarnya. Membentuk intelegensi dalam dunia nyata tidak hanya dengan sekedar tahu, namun dapat memecahkan permasalahan yang dihadapi di sekitar lingkungan secara berarti, relevan dan kontekstual. Pembelajaran siswa yang kontekstual, dapat melatih berpikir kritis, menguasai teknologi, kooperatif, dan berkolaborasi sangat diperlukan dalam memecahkan masalah (Insyasiska et al., 2015). Kreativitas juga merupakan salah satu komponen penting dalam pembelajaran kontekstual agar dapat sukses menghadapi dunia yang kompleks (Zubaidah, 2016). Munandar (2009) menyatakan pengembangan kreativitas tidak hanya memperhatikan pengembangan kemampuan berpikir kreatif, tetapi juga pemupukan sikap dan ciri-ciri kepribadian kreatif. Kreativitas dapat menggambarkan cara berpikir yang lebih adaptif dan dapat ditumbuh kembangkan melalui proses pemecahan masalah serta memiliki pemahaman yang tinggi (Sugiarto, 2015; Nikmah, 2015; Hwang et al. dalam Kusumaningrum (2016) dan Rati dkk.,2017).

Kreativitas di abad 21 memiliki peran penting untuk meningkatkan kualitas pendidikan di semua bidang pembelajaran termasuk ilmu pengetahuan, teknologi, teknik dan matematika (Science, Technic, Technologi and Mathematic) (Chotijah, 2017). Salah satu peran penting kreativitas adalah memberikan kesempatan kepada siswa untuk berpikir secara divergen. Artinya siswa diberikan kesempatan untuk berpendapat, berpikir dan mengambil kesimpulan secara alternatif atas dasar pengamatan, pengumpulan data, klasifikasi, analisis, sintesis dan evaluasi yang mereka lakukan sendiri (Saparahayuningsih, 2010).

Namun faktanya kreativitas siswa saat ini masih sangat rendah. Hal tersebut ditunjukkan oleh TIMSS tahun 2011, menyebutkan hasil sains Indonesia di urutan ke-40 dari 42 negara dengan nilai rata-rata 406. TIMSS membagi soal- soalnya menjadi empat katagori: Low Intermediate, High, Advance. Lebih dari 95\% siswa Indonesia hanya mampu sampai level menengah (intermediate). Hal ini menunjukkan bahwa siswa kurang mampu dalam memecahkan permasalahpermasalah berpikir tingkat tinggi. King, Goodson, \& Rohani dalam Insyasiska et al. (2015) menyatakan bahwa kemampuan berpikir tingkat tinggi (higher order thinking skills) termasuk didalamnya yaitu berpikir kreatif. Hasil reset PISA tahun 2009 menunjukkan kemampuan siswa Indonesia masih sangat rendah dengan skor sains 383. Indonesia menempati urutan ke 57 dari 65 negara (OECD, 2010). Hampir semua siswa Indonesia hanya menguasai pelajaran sampai level 3 saja, sementara negara lain banyak yang sampai level 4, 5, bahkan 6. Hal ini membuktikan bahwa kreativitas siswa masih sangat rendah, hal senada juga disampaikan oleh Rahman dalam Wardani (2015), menyatakan tingkat kreativitas siswa Indonesia dibandingkan negara-negara lain berada pada peringkat yang sangat rendah. Dari 9 negara yang diteliti yaitu Filipina, Amerika Serikat, Inggris, Jerman, India, RRC, Kamerun, Zulu, dan Indonesia menempati posisi terakhir. Sugiarto (2015) dan Santofani (2016) selama ini kreativitas peserta didik belum banyak dikembangkan di sekolah, padahal untuk menyelesaikan permasalahan yang semakin kompleks diperlukan kreativitas yang tinggi agar dapat memilih solusi yang tepat. Ditunjukan oleh hasil wawancara dengan guru mata pelajaran IPA yang dilaksanakan di SMP Negeri 3 Sukasada (2017), bahwa sebagian besar siswa kurang mampu menyesuaikan diri dengan perubahan maupun perkembangan ilmu pengetahuan dan teknologi, sulit untuk bisa memotivasi diri, dan kurang bisa mengembangkan kreativitas yang ada pada diri masingmasing siswa. Permasalahan tersebut tentunya merupakan hasil kondisi pembelajaran yang masih kurang efektif, dalam proses pembelajaran guru menggunakan model pembelajaran kooperatif tipe Student Teams Achievement Divisions (STAD). Menurut Nikmah (2015) model pembelajaran kooperatif tipe STAD 
belum mampu menyentuh ranah dimensi baik kognitif maupun psikomotor peserta didik itu sendiri. Pembelajaran kooperatif tipe STAD menempatkan guru sebagai sumber pemberi informasi utama sehingga proses belajar menjadi pasif. Hal ini yang mengakibatkan rendahnya kreativitas yang dimiliki pada masing-masing siswa.

Berdasarkan permasalahan tersebut perlu diupayakan model pembelajaran yang dapat memandu siswa dalam belajar berorientasi pada pengetahuan yang dimiliki siswa, salah satunya dengan menggunakan model pembelajaran yang relevan yaitu model pembelajaran berbasis proyek. PjBL (project-based lerning) sebagai pendekatan pembelajaran yang merangkum sejumlah ide-ide pembelajaran, yang didukung oleh teori-teori komprehensif yang melibatkan siswa dalam kegiatan penyelidikan yang kooperatif dan berkelanjutan, serta mengacu pada filosofis konstruktivistik, yaitu pengetahuan merupakan hasil konstruksi kognitif melalui suatu aktivitas siswa yang meliputi keterampilan maupun sikap ilmiah siswa sehingga siswa dapat mengkonstruksi pengetahuannya sendiri dan bermakna melalui pengalaman yang nyata. (Muliastawan et al., 2014; Desnylasari et al., 2016; Siwa et al., 2013; Akhiruddin dan Ibrohim, 2016). Tugas proyek juga dapat menjadikan siswa lebih percaya diri dan keterampilan berpikir kreatif berkembang lebih baik (Tasiwan, 2015). PjBL mengharuskan siswa untuk berpikir kritis, kreatif, analitis, menggunakan kemampuan berpikir yang tinggi, membutuhkan kolaborasi, komunikasi, pemecahan masalah dan pembelajaran yang mandiri (Astuti, 2015; Sumarni, 2016).

Penelitian lainnya tentang model PjBL telah dilakukan oleh Ardianti et al. (2017) yang menyatakan bahwa model project based learning dengan pendekatan science edutainment dapat meningkatkan kreativitas siswa. Penelitian serupa juga pernah dilakukan oleh Maula (2014), dengan hasil model PjBL berpengaruh terhadap hasil belajar kognitif siswa dan terjadi perbedaan yang signifikan terhadap kemampuan berpikir kreatif. Penelitian lainnya yang dilakukan oleh Alfiari (2016) yang menyatakan model pembelajaran berbasis proyek lebih efektif dalam meningkatkan kreativitas siswa dibandingkan dengan model pembelajaran konvensional (penerapan model kooperatif tipe STAD).

Model PjBL memiliki enam komponen, yaitu (1) penentuan pertanyaan mendasar, (2) mendesain proyek, (3) menyusun jadwal, (4) memonitoring kemajuan proyek, (5) menyajikan hasil dan (6) evaluasi (The George Lucas Educational Foundation, 2005). Kelebihan dari model pembelajaran ini yaitu (a) menumbuhkan partisipasi aktif siswa selama proses pembelajaran, (b) dapat mengembangkan penguasaan materi dan kreativitas siswa dalam memecahkan masalah, (c) meningkatkan kemauan siswa melaksanakan rancangan tindakan kreatif yang telah dibuat kelompoknya, (d) melatih siswa dapat bekerja sama dalam kerja kelompok (Astuti, 2015). Berdasarkan kelebihan yang telah dipaparkan, model ini mampu melatih siswa dalam mengembangkan penguasaan materi dan kreativitas siswa, mendorong siswa menghasilkan tindakan kreatif dan membuat proyek serta melibatkan siswa secara aktif dalam proses pembelajaran.

Slavin (2008) model pembelajaran kooperatif tipe STAD merupakan model pembelajaran kooperatif yang paling sederhana yang melibatkan kelompok kecil yang berbeda-beda tingkat kemampuan, jenis kelamin dan latar belakang etniknya untuk mencapai tujuan bersama dan mendorong siswa saling membantu, dan memotivasi. Ibrahim dalam Trianto (2014) menyatakan langkah-langkah model kooperatif tipe STAD antara lain (1) menyampaikan tujuan dan motivasi, (2) menyampaikan informasi, pengelompokan, (4) membimbing kelompok, (5) evaluasi, dan (6) penghargaan.

Berdasarkan kajian konseptual, perlu dilakukan penelitian lebih lanjut tentang pengaruh model pembelajaran berbasis proyek terhadap kreativitas siswa SMP pada pembelajaran IPA. Penelitian ini bertujuan untuk mendeskripsikan dan menjelaskan perbedaan pengaruh model PjBL dengan model kooperatif tipe STAD 
terhadap kreativitas siswa SMP pada pembelajaran IPA.

\section{METODE}

Penelitian ini merupakan penelitian eksperimen semu dengan rancangan nonequivalent pretest-posttest control group design. Populasi dalam penelitian ini adalah seluruh siswa kelas VII SMP Negeri 3 Sukasada yang dibagi menjadi 5 kelas VIIA, VIIB, VIIC, VIID, VIIE dengan jumlah sebanyak 150 orang. Sampel dipilih menggunakan teknik cluster random sampling sebanyak dua kelas yaitu siswa kelas VIID sebagai kelas eksperimen diterapkan model PjBL dan siswa kelas VIIE sebagai kelas kontrol diterapkan dengan model pembelajaran kooperatif tipe STAD.

Objek dalam penelitian ini adalah kreativitas siswa yang dikumpulkan menggunakan metode tes sebagai tes kreativitas. Tes yang digunakan adalah tes uraian sebanyak 20 butir. Karakteristik tes kreativitas sudah dinyatakan valid dan reliabel.
Data kreativitas dianalisis menggunakan teknik analisis statistik deskriptif dan statistik inferensial. Statistik deskriptif digunakan untuk mendeskripsikan skor rata-rata dan standar deviasi sedangkan statistik inferensial digunakan untuk menguji hipotesis penelitian menggunakan uji ANCOVA satu jalur dengan taraf signikikansi 0,05 . Sebelum pengujian hipotesis, dilakukan uji normalitas, uji homogenitas (varian antar kelompok), linearitas dan keberartian arah regresi dan uji homogenitas kemiringan garis regresi atau uji interaksi.

\section{HASIL DAN PEMBAHASAN Hasil}

Data penelitian ini berupa data kreativitas siswa yang diperoleh dari tes kreativitas siswa kelas eksperimen dan kelas kontrol.

Berdasarkan data yang telah dikumpulkan diperoleh skor rata-rata (M), persentase standar deviasi (SD), nilai maksimum, dan nilai minimum dari nilai pretest dan posttest disajikan pada Tabel 1

Tabel 1. Skor Rata-Rata, Standar Deviasi, Nilai Maksimum, dan Nilai Minimum Pretest dan Posttest Kreativitas Siswa

\begin{tabular}{lcccc}
\hline \multirow{2}{*}{ Statistik } & \multicolumn{2}{c}{ Pretest } & \multicolumn{2}{c}{ Posttest } \\
\cline { 2 - 5 } & PjBL & STAD & PjBL & STAD \\
\hline Skor Rata-Rata & 35,60 & 30,34 & 88,67 & 33,86 \\
Std. Deviation & 4,81 & 1,07 & 3,89 & 3,79 \\
Nilai Minimum & 28,00 & 0,00 & 82,70 & 28,00 \\
Nilai Maximum & 48,00 & 40,00 & 94,70 & 40,00 \\
\hline
\end{tabular}

Skor rata-rata pretest dan posttest kreativitas siswa pada kelompok model $\mathrm{PjBL}$ lebih tinggi dibandingkan dengan kelompok model kooperatif tipe STAD. Setelah diberikan perlakuan (posttest) skor rata-rata pada kelompok model $\mathrm{PjBL}$ mengalami peningkatan lebih tinggi dibandingkan dengan kelompok model kooperatif tipe STAD.

Jika digambarkan grafik batang skor rata-rata pretest dan posttest untuk kelompok model PjBL dan kelompok model kooperatif tipe STAD disajikan pada Gambar 1.
Perbandingan Skor Rata-Rata Pretest dan Posttest Kreativitas Siswa

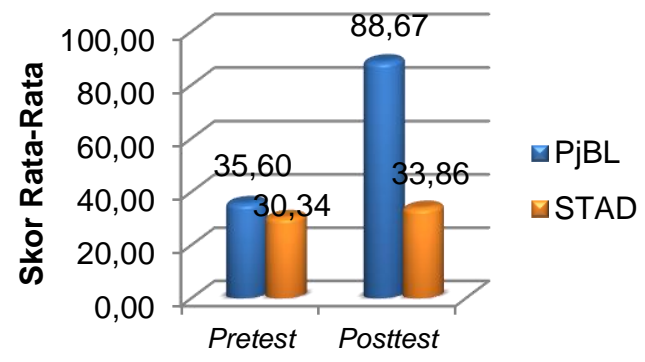

Gambar 1. Perbandingan Hasil Pretest dan Posttest

Berdasarkan hal tersebut dapat diketahui bahwa model PjBL lebih baik dalam meningkatkan kreativitas 
dibandingkan dengan model kooperatif tipe STAD.

Sebaran skor kreativitas siswa setiap dimensi disajikan pada Gambar 2.

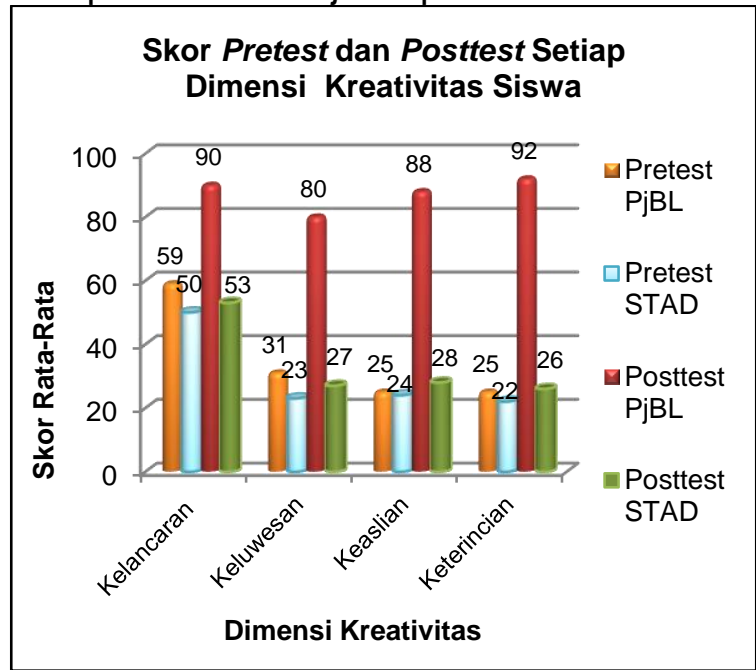

Gambar 2. Skor Pretest dan Posttest Setiap Dimensi Kreativitas Siswa

Berdasarkan Gambar 2 menunjukan skor rata-rata pretest masing-masing dimensi kreativitas pada kelompok model PjBL lebih tinggi daripada skor rata-rata pretest masing-masing dimensi kreativitas pada kelompok model kooperatif tipe STAD. Skor rata-rata posttest masingmasing dimensi kreativitas pada kelompok model PjBL mengalami peningkatan lebih tinggi daripada skor rata-rata posttest masing-masing dimensi kreativitas pada kelompok model kooperatif tipe STAD.

Hasil uji prasyarat menunjukkan bahwa data telah berdistribusi normal, memiliki varians data yang homogen, dan bersifat linear. Pada hasil uji keberartian arah regresi menunjukkan bahwa antara skor pretest dan posttest memiliki arah keberartian, serta tidak terdapat interaksi antara skor pretest dan posttest yang ditunjukkan dengan nilai signifikansi yang lebih besar dari 0,05 dari hasil uji interaksi. Oleh karena itu, semua uji prasyarat telah memenuhi untuk dapat dilakukan uji statistik ankova.

Hasil analisis statistik pengaruh model pembelajaran berbasis proyek terhadap kreativitas siswa disajikan pada Tabel 3.

Tabel 3. Hasil Uji Ancova

\begin{tabular}{lrrrrr}
\hline \multicolumn{1}{c}{ Source } & $\begin{array}{c}\text { Type III Sum of } \\
\text { Squares }\end{array}$ & Df & Mean Square & F & Sig. \\
\hline Corrected Model & 2079.950 & 1 & 2079.950 & 5.108 & .028 \\
Intercept & 2025.482 & 1 & 2025.482 & 4.974 & .030 \\
Pretest & 2079.950 & 1 & 2079.950 & 5.108 & .028 \\
Error & 24023.493 & 59 & 407.178 & & \\
Total & 153346.000 & 61 & & & \\
Corrected Total & 26103.443 & 60 & & & \\
\hline
\end{tabular}

Berdasarkan Tabel 3 menunjukkan angka signifikansi sebesar 0,028 lebih kecil dari 0,05 , dengan demikian dapat diambil keputusan bahwa $\mathrm{H}_{0}$ ditolak dan $\mathrm{H}_{\mathrm{a}}$ diterima sehingga terdapat perbedaan kreativitas antara siswa yang diberi perlakuan dengan menggunakan model PjBL dan model pembelajaran koopetarif tipe STAD.

\section{Pembahasan}

Hasil penelitian menunjukkan bahwa kreativitas siswa yang dibelajarkan menggunakan model PjBL lebih baik dari kreativitas siswa yang dibelajarkan menggunakan model pembelajaran kooperatif tipe STAD. Kreativitas awal siswa (pretsest) dalam penelitian ini merupakan variabel kovariat. Skor rata-rata pretest tidak jauh berbeda antara kelompok model PjBL dan kelompok model kooperatif tipe STAD. Skor rata-rata pretest tersebut dapat dikendalikan sehingga tidak mempengaruhi kreativitas akhir siswa. Hal ini dipertegas dengan hasil uji interaksi antara kreativitas awal siswa dengan model pembelajaran yang menunjukkan tidak terdapat interaksi antara kreativitas awal siswa dengan model pembelajaran terhadap kreativitas akhir siswa. Artinya kreativitas akhir siswa tidak dipengaruhi 
oleh variabel kovariat melainkan dipengaruhi oleh model pembelajaran yang diberikan. Setelah diberikan perlakukan diperoleh kreativitas akhir siswa yang diukur menggunakan posttest. Skor ratarata posttest kelompok model PjBL lebih tinggi dibandingkan dengan kelompok model kooperatif tipe STAD. Hasil penelitian ini juga diperkuat oleh penelitian yang dilakukan Chasanah et al., (2017), Insyasiska et al., (2015), Astuti (2016) dan Rati dkk., (2017) yang menyatakan bahwa model project based learning (PjBL) dapat meningkatkan kemampuan berpikir kreatif siswa.

Kreativitas siswa pada kelompok model PjBL lebih tinggi dibandingkan dengan kelompok model kooperatif tipe STAD dikarenakan dalam proses pembelajaran berbasis proyek terdapat kegiatan mendesain proyek. Pada kegiatan ini, siswa diberikan kesempatan untuk merancang atau mendesain proyek dari pertanyaan yang sudah dibuat. Kegiatan merancang proyek merupakan kegiatan penting yang harus dilakukan karena kegiatan ini menjadikan siswa memiliki gambaran dari proyek yang akan mereka kerjakan. Rancangan ini dibuat berdasarkan ide-ide yang dimiliki masingmasing siswa sehingga siswa mampu memecahkan persoalan-persoalan yang dimiliki menjadi sebuah rancangan proyek. Kegiatan ini memiliki kontribusi untuk melatih siswa berpikir lancar karena pada proses ini siswa dituntut untuk memberikan banyak gagasan berupa ide-ide untuk menyelesaikan masalah yang diperoleh dari menonton video. Kegiatan ini memiliki kontribusi untuk melatih siswa berpikir luwes karena siswa dituntut untuk dapat mengembangkan ide-ide dari ide yang sudah diberikan. Dari pengembangan ideide tersebut, nantinya siswa dapat merancang proyek sesuai dengan keterampilan yang dimiliki masing-masing kelompok. Kegiatan ini memiliki kontribusi untuk melatih siswa berpikir terperinci karena siswa dituntut untuk dapat menggambarkan rancangan proyek dengan teliti dan seksama. Rancangan proyek harus mengandung semua komponen yang terlibat didalam proyek yang dibuat. Kegiatan ini juga memiliki kontribusi untuk melatih siswa berpikir orisinil karena siswa dituntut untuk dapat mengkonstruksi pengetahuan yang dimiliki berdasarkan pengalaman nyata yang dimiliki sebelumnya. Dari konstruksi pengetahuan tersebut nantinya dapat melahirkan ide-ide baru untuk merancang proyek. Siswa juga menggambarkan rancangan proyek tersebut secara mandiri (tanpa bantuan pihak selain kelompok yang bertugas). Hal ini sejalan dengan teori konstruktivistik yang menyatakan belajar sebagai proses pembentukan (konstruksi) pengetahuan berdasarkan pengalaman nyata oleh pembelajar itu sendiri sehingga dapat menghasilkan banyak ide atau gagasan (Ummi dan Mulyaningsih, 2016). Siwa et al., 2013 mengungkapkan pembelajaran berbasis proyek mengacu pada filosofis konstruktivistik, yaitu pengetahuan merupakan hasil konstruksi kognitif melalui suatu aktivitas siswa yang meliputi keterampilan maupun sikap ilmiah siswa sehingga siswa dapat mengkonstruksi pengetahuannya sendiri dan bermakna melalui pengalaman yang nyata. Doplet dalam Utami (2015) dan Rati dkk, (2017) bahwa pada saat siswa merencanakan desain proyek dan melakukan penelitian maka kemampaun berpikir kreatif dapat dikembangkan.

Dari rancangan yang telah dibuat, selanjutnya siswa menyusun langkahlangkah pembuatan proyek. Solusi langkahlangkah pembuatan proyek dipecahkan secara individu terlebih dahulu sebelum dipecahkan bersama teman kelompoknya. Solusi langkah-langkah pembuatan proyek yang telah diajukan oleh masing-masing siswa selanjutnya didiskusikan bersama teman kelompok untuk memilih langkahlangkah yang tepat, selanjutnya langkahlangkah pembuatan proyek tersebut diurutkan dari awal pembuatan proyek hingga menjadi produk miniatur proyek. Kegiatan ini memiliki kontribusi untuk melatih siswa berpikir lancar karena pada proses ini siswa dituntut untuk memberikan banyak gagasan dalam menyusun langkahlangkah pembuatan proyek dengan baik sehingga siswa mendapatkan pengalaman belajar lebih bermakna. Hal ini sesuai dengan teori belajar kontekstual yang memandang bahwa proses belajar benar- 
benar berlangsung hanya jika siswa mampu mengkaitkan materi pembelajaran dengan konteks dunia nyata yang dihadapi sehingga pembelajaran menjadi lebih bermakna (Sugiyanto, 2012). Rati dkk. (2017) dan Titu (2015) menyatakan pembelajaran berbasis proyek memberikan kebebasan kepada siswa untuk merencanakan aktivitas belajar sehingga menciptakan pengalaman belajar yang lebih menarik dan bermakna untuk siswa.

Kegiatan selanjutnya menyusun jadwal penyelesaian proyek. Jadwal penyelesian proyek berisikan pelaksanaan kegiatan, pembagian tugas masing-masing anggota kelompok serta alokasi waktu yang dibutuhkan untuk menyelesaikan proyek tersebut. Siswa dituntut untuk dapat membagi antara bobot masing-masing pelaksanaan kegiatan dan alokasi waktu yang dibutuhkan agar sesuai dengan tingkat kesulitan proyek yang dibuat. Siswa juga harus mampu membagi tugas masingmasing anggota kelompok agar bobot masing-masing anggota kelompok sama sehingga tidak ada dari anggota kelompok yang terlalu dibebankan. Kegiatan ini memiliki kontribusi untuk melatih siswa berpikir rinci karena siswa dituntut untuk cermat dalam membagi bobot masingmasing kegiatan dengan alokasi waktu yang dibutuhkan serta bobot masingmasing tugas anggota kelompok harus sama sehingga tidak ada kegiatan yang kekurangkan alokasi waktu dan tidak ada anggota yang dibebankan tugas terlalu banyak. Hal ini sejalan dengan pendapat Muliastawan et al. (2013) yang menyatakan kegiatan proyek memfokuskan pada pengembangan produk atau unjuk kerja (performance), yang secara umum pebelajar melakukan pengorganisasian kegiatan belajar kelompok mereka.

$$
\text { Rancangan proyek, langkah- }
$$

langkah pengerjaan proyek dan menyusun jadwal yang selanjutnya direalisasikan kedalam pengerjaan proyek. Siswa diberikan kesempatan untuk mengerjakan proyek sesuai dengan aktivitas yang telah dilakukan sebelumnya. Pengerjaan proyek memungkinkan siswa untuk menghasilkan ide-ide yang mendukung pengerjaan proyek dan menggali informasi-informasi dari berbagai sumber serta mengolah sumber informasi yang didapat ke dalam bentuk proyek. Siswa mengerjakan proyek secara berkelompok dan bekerjasama dengan rekan sekelompoknya. Kerjasama dapat menumbuhkan hubungan sosial dan rasa solidaritas dengan sesama. Dari proyek yang dikerjakan terdapat beberapa kelompok yang mengalami kesulitan dalam penggunaan alat yang masih kurang memadai. Kendala tersebut dapat diminimalisir dengan mengganti alat tersebut dengan alat yang memiliki fungsi yang hampir sama. Kegiatan ini memiliki kontribusi untuk melatih siswa berpikir lancar karena pada proses ini siswa dituntut untuk dapat menghasilkan ide-ide yang dapat menyelesaikan proyek dengan baik shingga dapat direalisasian kedalam produk nyata. Kegiatan ini memiliki kontribusi untuk melatih siswa berpikir luwes karena siswa dituntut untuk dapat mengembangkan berbagai ide yang dimiliki kedalam pengerjaan proyek. Siswa juga harus mampu mengantisipasi kendala-kendala yang mungkin terjadi sehingga pengerjaan proyek tidak terhampat dengan adanya kendala tersebut. Kegiatan ini memiliki kontribusi untuk melatih siswa berpikir rinci karena siswa dituntut untuk cermat dan teliti dalam mengerjakan proyek sehingga produk yang dihasilkan menjadi kompleks. Kegiatan ini juga memiliki kontribusi untuk melatih siswa berpikir orisinil karena siswa dituntut untuk mengerjakan proyek secara mandiri dalam masing-masing kelompok, menghasilkan ide-ide baru sehingga produk yang dihasilkan bernilai tinggi. Hal ini sejalan dengan teori belajar konstruktivistik Vygotsky yang memandang bahwa pengetahuan dikonstruksi secara kolaboratif antar individual berdasarkan pengalaman nyata yang diperoleh sehingga dapat menghasilkan pembelajaran yang lebih bermakna (Masbied, 2011). Model pembelajaran berbasis proyek merupakan suatu model pembelajaran yang menyangkut pemusatan pertanyaan dan masalah bermakna, pemecahan masalah, pengambilan keputusan, proses pencarian berbagai sumber, pemberian kesempatan kepada anggota untuk bekerja secara kolaborasi serta melakukan kegiatan investigasi (Rati dkk, 2017 dan Siwa at al., 2013). Pembelajaran dengan model 
pembelajaran berbasis proyek berfokus pada konsep yang melibatkan siswa dalam kegiatan pengerjaan proyek, memberi peluang siswa bekerja secara otonom, mengonstruk pengetahuan yang dimiliki dan puncaknya menghasilkan karya atau produk nyata dan hasilnya kemudian dipresentasikan (Doppelt dalam Akhiruddin et al., 2016). Prinsip otonom dalam pembelajaran berbasis proyek dapat diartikan sebagai kemandirian siswa dalam melaksanakan proses pembelajaran, yaitu bebas menentukan pilihannya sendiri, bekerja dengan minimal supervise, dan bertanggung jawab (Suhartadi dalam Nayono dan Nuryadin, 2013).

Dilain pihak, proses pembelajaran kooperatif tipe STAD memiliki kontribusi yang berbeda dengan model pembelajaran berbasis proyek. Perbedaan tersebut terletak pada rancangan proyek, langkahlangkah pembuatan proyek, dan menyusun jadwal. Siswa yang dibelajarkan menggunakan model kooperatif tipe STAD mengerjakan proyek berdasarkan langkahlangkah yang ada pada Lembar Kegiatan Proyek (LKP). Proses pembelajaran tersebut kurang efektif karena siswa tidak diberi kesempatan untuk mengkonstruksi pengetahuan yang dimiliki melalui pembuatan rancangan proyek sehingga siswa kurang mengalami proses berpikir kreatif. Siswa juga tidak diberi kesempatan untuk merencanakan aktivitas belajarnya sendiri dan mengorganisasi kegiatan belajar melalui penyusunan langkahlangkah pembuatan proyek serta penyususnan jadwal sehingga aktivitas siswa terpaku pada LKP yang diberikan tanpa ada aktivitas-aktivitas yang mampu mendukung pengembangan kreativitas lebih lanjut. Nikmah (2015) menyatakan model kooperatif tipe STAD cenderung mengandalkan metode ceramah dan pemberian tugas yang cenderung berpusat pada guru dan kurang melibatkan siswa secara aktif dan kurang membiasakan siswa untuk mampu berpikir kreatif dalam belajar.

Secara lebih rinci, kreativitas awal siswa tertinggi pada kelompok model PjBL terdapat pada dimensi kreativitas yaitu keterincian. Hal ini dikarenakan selama proses pembelajaran siswa kreatif serta teliti dalam mengemukakan ide-ide yang dimiliki, hal ini tidak lain disebabkan oleh model pembelajaran yang digunakan sehingga siswa semakin lancar mengemukan gagasan yang dimiliki. Menurut Juandi (2017) penggunaan model PjBL memberikan pengaruh terhadap kreativitas siswa. Penggunaan model PjBL dalam proses belajar mengajar menjadikan siswa mudah memahami materi, konsep, memberikan peluang kepada siswa untuk menuangkan ide dan gagasan dalam mengkonstruk pengetahuannya. Ditnjau dari kreativitas siswa selama proses pembelajaran, siswa sangat antusias mengerjakan proyek yang sudah rancang sebelumnya, siswa juga aktif menyampaikan ide-ide yang dimiliki demi menyempurnakan proyek yang mereka kerjakan secara berkelompok (kolaboratif). Juandi dan Anhar (2017) dan Akhiruddin et al. (2016) PjBL menekankan pada pembelajaran yang kompherensip mengikut sertakan siswa melakukan investigasi secara kolaboratif. Muliastawan et al. (2014); dan Kusumaningrum (2016) PjBL dapat memberikan pemahaman pada siswa lebih mendalam dalam segi analisis teori maupun praktek (proyek). Pradita et al., (2015) dan Insyasiska et al. (2015) pendukung keterlaksanaan pembelajaran adalah kreativitas. Pembelajaran yang dilakukan dalam model PjBL dapat menumbuhkan upaya siswa membangun representasi memori yang kompleks dan kaya pengalaman, yang menunjukkan tingkat keterhubungan yang kuat antara kreativitas semantik, episodik, dan tindakan (Santyasa, 2011).

Kreativitas awal siswa tertinggi pada kelompok model kooperatif tipe STAD terdapat pada dimensi kreativitas yaitu kelancaran. Hal ini dikarenakan model kooperatif tipe STAD memberikan peluang kepada siswa hanya sebatas menghafal, jadi siswa cenderung menghafalkan katakata yang sudah disusun sebelumnya tanpa diperkaya dengan ide-ide baru.

Kreativitas akhir siswa terendah pada kelompok model PjBL yaitu keluwesan, hal ini dikarena siswa belum sepenuhnya mampu mengembangkan ideide yang miliki. Kreativitas akhir siswa terendah pada kelompok model kooperatif 
tipe STAD terdapat pada dimensi kreativitas yaitu keterincian, hal ini dikarenakan siswa kurang mampu dalam menyampaikan ideide yang dimiliki sehingga ide yang disampaikan kesulitan kurang rinci.

Dilihat dari aktivitas siswa, terlihat adanya hubungan yang sejalan antara aktivitas dengan kreativitas siswa yang dibelajarkan dengan model PjBL. Antika, (2017) keefektifan penggunaan model PjBL didukung oleh aktivitas belajar siswa yang tinggi. Hal ini sejalan dengan skor rata-rata aktivitas belajar siswa pada masing-masing indikator, aktivitas belajar siswa pada kelompok model PjBL lebih aktif dari kelompok model kooperatif tipe STAD. PjBL sebuah pembelajaran dengan aktivitas jangka panjang yang melibatkan siswa dalam merancang, membuat, dan menampilkan produk untuk mengatasi permasalahan dunia nyata (Herawan, 2016).

Hasil penelitian ini belum tercapai secara maksimal karena terdapat kendala selama proses pembelajaran di kelas. Adapun kendala yang dialami dalam penelitian yaitu pola belajar siswa yang sulit untuk diubah. Siswa belum terbiasa belajar melakukan kegiatan proyek, akibatnya pada kegiatan pembelajaran masih banyak bertanya sehingga menyita alokasi waktu yang tersedia.

Kendala tersebut berusaha diminimalisir dengan cara mendorong siswa untuk bekerja sama dalam melakukan kegiatan proyek agar siswa memiliki keterampilan dalam membuat proyek dan memecahkan masalah bersama dengan kelmpoknya tanpa harus bertanya secara terus menerus kepada guru. Guru juga dapat menggunakan model $\mathrm{PjBL}$ yang sesuai dengan materi pelajaran agar siswa terbiasa dalam belajar melakukan kegiatan proyek.

\section{SIMPULAN DAN SARAN}

Berdasarkan hasil penelitian dan pembahasan yang telah dipaparkan dapat disimpulkan bahwa hasil uji ankova menunjukkan nilai signifikansi sebesar 0,028 yang berarti terdapat perbedaan kreativitas antara siswa siswa yang diberi perlakuan dengan menggunakan model $\mathrm{PjBL}$ dan model pembelajaran koopetarif tipe STAD. Siswa yang dibelajarkan menggunakan model PjBL memiliki kreativitas lebih baik dibandingkan dengan siswa yang dibelajarkan menggunakan model kooperatif tipe STAD rata-rata skor posttest kelompok model PjBL adalah 88,67 sedangkan kelompok model kooperatif tipe STAD adalah 33,86.

Berdasarkan temuan penelitian ini, disarankan (1) Bagi praktisi pendidikan, khususnya yang terlibat dalam pembelajaran IPA disarankan untuk mempertimbangkan model pembelajaran berbasis proyek ini sebagai salah satu alternatif model pembelajaran yang dapat diterapkan di kelas terutama apabila ingin meningkatkan kreativitas siswa.

\section{DAFTAR RUJUKAN}

Akhiruddin, H. Susilo \& Ibrohim (2016). "Pengaruh Penggunaan Modul Inkuiri Dipadu PjBL Berbahan Ajar Potensi Lokal Terhadap Keterampilan Proses Sains Siswa SMA". Jurnal Pendidikan: Teori, Penelitian dan Pengembangan. 1 (10), 1964-1968. EISSN:2502-471X. tersedia pada: http://journal.um.ac.id /index.php/ diakses tanggal 20 Maret 2018

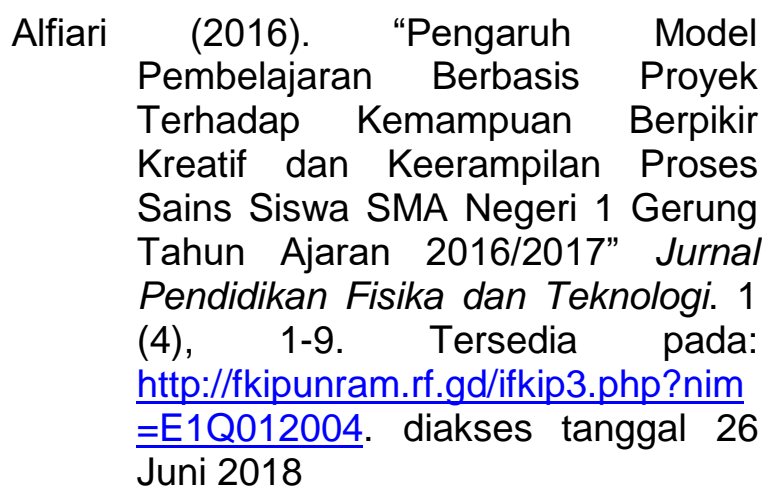

Ardianti, S.D., I. A. Pratiwi \& M. Kanzunnudin (2017). " Implementasi Project based learning (PjBL) Berpendekatan Science Edutainment Terhadap Kreativitas Peserta Didik". Jurnal Refleksi Edukatika. 7 (2), 145-150. p-ISSN: 2087-9385 e-ISSN: 2528-696X. tersedia pada: http://jurnal.umk.ac.id/index.php /RE. diakses tanggal 19 Januari 2018 
Antika, R. N. \& Sulton N. (2017). "Pengaruh Model Project Based Learning Pada Mata Kuliah Seminar Terhadap Keterampilan Berpikir Kreatif Mahasiswa" Jurnal Pendidikan Biologi Indonesia. 3 (1), 1-10. pISSN: 2442-3750; e-ISSN: 25276204. Tersedia pada: http://ejournal. umm.ac.id/index.php/ipbi. diakses tanggal 10 Mei 2018.

Astuti, R. 2015. "Meningkatkan Kreativitas Siswa Dalam Pengolahan Limbah Menjadi Trash Fashion Melalui PjBL". Bioedukasi 8 (2) 37-41. ISSN: 1693-2654. Tersedia pada: http://download.portalgaruda.org/ diakses tanggal 14 juni 2017

Chasanah, A. R. U., N. Khoiri \& H. Nuroso. (2016). "Efektivitas Model Project Based Learning terhadap Keterampilan Proses Sains dan Kemampuan Berpikir Kreatif Siswa pada Pokok Bahasan Kalor Kelas X SMAN 1 Wonosegoro Tahun Pelajaran 2014/2015" JP2F, 7 (1). ISSN 2086-2407. Tersedia pada: http://ejurnal.upgrismg.ac.id/index.p hp/JP2F. diakses tanggal 10 Mei 2018.

Chotijah, S. 2017. Pentingnya Kreativitas dan Imajinasi untuk Generasi Penerus (Core Skill). Tersedia pada: http://sitichotijah.gurusiana.id/article/ pentingnya-kreativitas-danimajinasiuntuk-generasi-penerus-core-skill-0. diakses tanggal 22 Juni 2018.

Desnylasari, E., S. Mulyani \& B. Mulyani. $2016 . \quad$ "Pengaruh Model Pembelajaran Project Based Learning dan Problem Based Learning Pada Materi Termokimia Terhadap Prestasi Belajar Siswa Kelas XI SMA Negeri 1 Karanganyar Tahun Pelajaran 2015/2016". Jurnal Pendidikan Kimia, Universitas Sebelas Maret. Vol. 5 No. 1 (Hal. 134-142) ISSN 2337-9995. Tersedia pada:http://jurnal.fkip.uns.ac.id/ inde.x.php/kimia. diakses tanggal 20 mei 2017
Herawan, H. E. \& Luluh R. 2016. "Pengaruh Aktivitas Belajar Siswa dalam Penerapan Model Project Based Learning Berbasis Saintifik Terhadap Hasil Belajar Pada Mata Pelajaran Akuntansi”. Edunomic. 4 (1) 18-29. Tersedia pada: http://www.fkipunswagati.ac.id/ diakses tanggal 10 Mei 2018

Insyasiska, D., S. Zubaidah \& H. Susilo. (2015). "Pengaruh Project Based Learning Terhadap Motivasi Belajar, Kreativitas, Kemampuan Berpikir Kritis, Dan Kemampuan Kognitif Siswa Pada Pembelajaran Biologi". Jurnal Pendidikan Biologi 7 (1) 9-21 tersedia pada: http://journal2.um. ac.id/index.php/ diakses tanggal 14 Juni 2017

Juandi, T., \& Anhar. (2017). "Pengaruh Model Pembelajaran Project Based Learning Ditinjau dari Kreativitas Siswa Terhadap Prestasi Belajar". Kappa Journal. e-ISSN 2450-2590, 1 (1). Tersedia pada: http://ejournal.hamzanwadi.ac.id/ Diakses tanggal 10 Mei 2018.

Kusumaningrum, S. \& D. Djukri. (2016). "Pengembangan Perangkat Pembelajaran Model Project Based Learning (PjBL) untuk Meningkatkan Keterampilan Proses Sains dan Kreativitas". Jurnal Inovasi Pendidikan IPA, ISSN: 2406-9205, Online ISSN: 2477-4820, 2 (2) 241 -251 .

Masbied. (2013). Teori Konstruktivisme Vygotsky dalam Pembelajaran Matematika. Tersedia pada: https://masbied.files.wordpress.com/ 2011/05/modul-matematika-teoribelajar-vygotsky.pdf. diakses tanggal 28 Juni 2018.

Maula, M. M., J. Prihatin, \& K. Fikri. (2014). "Pengaruh Model PjBL (ProjectBased Laerning) terhadap kemampuan berpikir Kreatif dan 
Hasil Belajar Siswa pada Materi Pengelolaan Lingkungan". Artikel IImiah Mahasiswa, (hml.1-6).

Muliastawan, I. K., N. Suharsono \& I M. Kirna. 2014. "Pengaruh Model Pembelajaran Berbasis Proyek Terhadap Pemahaman Konsep Dan Keterampilan Memperbaiki Sistem Transmisi di SMK". e-Journal Program Pascasarjana Universitas Pendidikan Ganesha Program Studi Teknologi Pembelajaran. Volume 4

Munandar, U. 2009. Pengembangan Kreativitas Anak Berbakat. Jakarta: Rineka Cipta.

Naryono, S. E. \& Nuryadin E. R. (2013). “ Pengembangan Model Pembelajaran Project Based Learning pada Mata Kuliah Computer Aided Design". Jurnal Pendiidkan Teknologi dan Kejuruan. 21 (4). 340-347. Tersedia pada: https://media.neliti.com/media/public ations/163950-ID-pengembanganmodel-pembelajaran-project.pdf. diakses tanggal 5 Juli 2018

Nikmah, H., Wildan \& Muntari. 2015. "Implementasi Model Kooperatif Tipe STAD Terhadap Hasil Belajar Kimia Siswa Ditinjau Dari Keterampilan Berpikir Kreatif" VIII, (1), 19-26. Tersedia pada: download.portalgaruda.org/ Diakses tanggal 21 Juni 2017

Pradita, Y., B. Mulyani \& T. Redjeki. (2015). "Penerapan Model Pembelajaran Project Based Learning untuk Meningkatkan Prestasi Belajar dan Kreativitas Siswa Pada Materi Pokok Sistem Koloid Kelas XI IPA Semester Genap Madrasah Aliyah Negeri Klaten Tahun Pelajaran 2013/2014" Jurnal Pendidikan Kimia. 4 (1), 89-96. ISSN 23379995. Tersedia pada: http://jurnal. fkip.uns.ac.id/index.php/kimia. diakses tanggal 10 Mei 2018.
Purworini, S. (2006). "Pembelajaran Berbasis Proyek Sebagai Upaya Mengembangkan Habit Of Mind Studi Kasus Di SMP Nasional KPS Balikpapan". Jurnal Pendidikan Inovatif, Vol.1, No.2, Maret 2006. Tersedia pada: Http://Jurnalipi. Wordpress/. Diakses Pada 10 Mei 2018

Rati, N. W., N. Kusmaryanti, dan N. Rediani. (2017). " Model Pembelajaran Berbasis Proyek, Kreativitas dan Hasil Belajar Mahasiswa" 6 (1) 60-71. P-ISSN: 2303-288X E-ISSN: 2541-7207 Tersedia pada: https://ejournal. undiksha.ac.id/index.php/JPI/article/ view/9059 Diakses tanggal 12 Juni 2017

Santofani, A. \& Dadan Rosana. 2016. "Pengembangan Tes Kreativitas pada Pembelajaran Fisika dengan Pendekatan Inkuiri pada Materi Teori Kinetik Gas". Jurnal Inovasi Pendidikan IPA, 2 (2), 134 - 144. Tersedia pada: http://journal.uny. ac.id/index.php/jipi/article/view/6373/ 9016. diakses tanggal 14 Juni 2017.

Santyasa, I W. 2006. Pembelajaran Inovatif: Model Kolaboratif, Basis Proyek, dan Orientasi NOS. Makalah. Disajikan Dalam Seminar Di Sekolah Menengah Atas (SMA) Negeri 2 Di Semarapura.

Saparahayuningsih, S. 2010. "Peningkatan Kecerdasan dan Kreativitas Siswa (Improving Students' Intelligence and Creativity)". (1) 1. Tersedia pada:http://download.portalgaruda.o $\mathrm{rg} /$ article.php?article $=136837 \& \mathrm{val}=5$ $\underline{679}$ diakses pada 22 Juni 2018.

Siwa. IB., Muderawan, I W., \& Tika, I N., (2013)."Pengaruh Model Pembelajaran Berbasis Proyek dalam Pembelajaran Kimia terhadap Keterampilan Proses Sains ditinjau dari Gaya Kognitif Siswa". E-Journal Program Pascasarjana Universitas 
Pendidikan Ganesha Program Studi IPA, Volume 3, 1-13.

Slavin, R. E. 2008. Cooperative Learning: Teori, riset, dan praktik. Bandung: Nusa Media.

Sugiarto, Agung \& Djukuri. 2015. "Pembelajaran Berbasis Sets sebagai Upaya Meningkatkan Kreativitas dalam Pemecahan Masalah Pencemaran Lingkungan". Jurnal Inovasi Pendidikan IPA, 1 (1) 1-11. Tersedia pada: http://journal. uny.ac.id/index.php/ diakses tanggal 21 Juni 2017

Sugiyanto. (2012). "Penerapan Pendekatan Kontekstual untuk Meningkatkan Aktivitas Belajar Matematika Sekolah Dasar Negeri 01 Pontianak Utara" Artikel Penelitian. Tersedia pada:https://media.neliti.com/media/ publications/216114-penerapanpendekatan-kontekstual-untuk-m.pdf diakses tanggal 27 Juni 2018

Sumarni, W., S. Wardani, Sudarmin \& D. N. Gupitasari. 2016. "Project Based Learning (PBL) To Improve Psychomotoric Skills: A Classroom Action Research". 5 (2) (2016) 157163 Jurnal Pendidikan IPA Indonesia. Tersedia pada: http:// journal.unnes.ac.id/index.php/ipii diakses tanggal 20 Mei 2017

Tasiwan. 2015. "Efek Pembelajaran Berbasis Proyek Terbimbing Terhadap Perkembangan Keterampilan Proses Dan Sikap Sains Siswa". Berkala Fisika Indonesia Volume 7 Nomor 2. Tersedia pada: http://journal.uad.ac. id/index.php/BFl/article/view/3399/ 1937 diakses tanggal 14 juni 2017

The George Lucas Educational Foundation. 2005. Instructional Module Project Based Learnin. http://www.edutopia. org/modules/PBL/whatpbl.php. diakses tanggal 3 Januari 2018

Titu, M. A. (2015). Penerapan Model Pembelajaran Project Based
Learning (PjBL) untuk Meningkatkan Kreativitas Siswa pada Materi Konsep Masalah Ekonomi”. Prosiding Seminar Nasional.

Trianto, I. B. 2014. Mendesain Model Pembelajaran Inovatif, Progresif, dan Kontekstual Konsep, Landasan, dan Implementasinya pada Kurikulum 2013 (Kurikulum Tematik Integratif/KTI). Jakarta: Pramedia Group

Ummi, H. U. \& I. Mulyaningsih. (2016). Penerapan Teori Konstruktivistik pada Pembelajaran Bahasa Arab di lain Syekh Nurjati Cirebon". Jurnal Indonesia Language Education and Literature. 1 (2). 162-172. Tersedia pada:http://www.syekhnurjati.ac.id/ju rnal/index.php/jeill/. Diakses tanggal 29 Juni 2018.

Utami, R. N., R. M. Probosari \& U. Fatmawati. 2015. "Pengaruh Model Pembelajaran Project Based Learning Berbantuan Instagram terhadap Kemampuan Berpikir Kreatif Siswa Kelas X SMA Negeri 8 Surakarta". 4 (1) 47-52. ISSN: 22526897. Tersedia pada: https://jurnal. uns.ac.id/pdg/article/view/5364/4762 diakses tanggal 10 Mei 2018

Zubaidah, S. 2016. Keterampilan Abad ke21: Keterampilan yang diajarkan melalui Pembelajaran. Makalah. Disampaikan pada Seminar Nasional Pendidikan dengan tema "Isu-isu Strategis Pembelajaran MIPA Abad 21, tanggal 10 Desember 2016 di Program Studi Pendidikan Biologi STKIP Persada Khatulistiwa Sintang - Kalimantan Barat. 